\title{
Between Politics and the Political: reading Hans J. Morgenthau's double critique of depoliticisation
}

\author{
Vassilios Paipais* \\ vp31@st-andrews.ac.uk
}

\begin{abstract}
This paper situates H. Morgenthau's thought in the context of postfoundationalist theorisations of the difference between politics and the political. In doing so, it shows how Morgenthau's sophisticated realism refused to circumscribe the antagonistic dimension of politics and introduced the study of international politics as a struggle with negativity, temporality and contingency in the wake of the crisis of foundationalism in late modernity. Morgenthau's tarrying with the negative is primarily revealed in his irresolvable tragic oscillation between Nietzschean skepticism and Kantian moralism. Nevertheless, due to its antinomic premises, Morgenthau's tragic vision of politics can still be viewed as stopping a step shorter of its full-blown critical potential. It is not the purpose of this paper, however, to award or withhold credentials of criticality but to recast Morgenthau's theory of the political as an instructive attempt to a post-foundational political ontology. This may, eventually, serve a purpose far broader than restoring classical realism's latent reflexivity; it may prompt an argument about the conditions and challenges involved in practicing international theory as a constant critique of depoliticisation.
\end{abstract}

Keywords: post-foundationalism, depoliticisation, Morgenthau, the political, politics

\section{Introduction}

In an insightful article on the question of foundations in International Relations (IR), Marc Doucet argued that not only mainstream but even critical contributions to IR theory are predicated on a foundationalist bias which, ultimately, leads to the eclipse of the political from the relevant debates. ${ }^{1}$ Recently, Milja Kurki put forward a similar plea for an open recognition of the political nature of meta-theoretical debates in the field. ${ }^{2}$ Both Doucet and Kurki, among others, touch on an extremely sensitive issue regarding the nature and legitimacy of critical theorising in International Relations; one that is inextricably linked to the ontological claims IR theorists make not only about their subject matter but also about the nature of theory itself and, if one accepts the interlacing of theory and practice, the normative underpinnings of political

\footnotetext{
*I would like to thank Beate Jahn, Douglas Bulloch, Sean Molloy, Felix Berenskoetter, Andrew Neal, Ilias Papagiannopoulos and three anonymous reviewers for reading and commenting on previous drafts of this paper. The usual disclaimer applies.

${ }^{1}$ Mark Doucet, 'Standing Nowhere(?): Navigating the Third Route on the Question of Foundation in International Theory', Millennium: Journal of International Studies, 28, no. 2, (1999): 289-310.

2 Milja Kurki, 'The Politics of the Philosophy of Science', International Theory, 1, no. 3, (2009): $440-454$
} 
action as well. ${ }^{3}$ In the aftermath of the post-positivist critique, foundationalism the claim that there are unshakable grounds for judging between rival philosophical, epistemological or praxeological standpoints- is either discredited or becoming increasingly difficult to justify. Foundationalism is arguably losing ground and credibility; yet, the terrifying spectre of relativism or practical irrelevance that a complete surrender to anti-foundationalism would entail spawns the development of a middle-ground accommodationism that would secure the possibility of knowledge or the ground for political action without falling back to dogmatic or uncritical positions. The burgeoning literature on the evils of rigid paradigmatic thinking in the discipline as opposed to the merits of an eclectic or pluralist sensibility is a testament to the growing anxiety the retreat of foundations is prompting among theoretical circles and the pragmatic responses it provokes. ${ }^{4}$

A recent, widely discussed, attempt to advance this pragmatic mood calls for a strategy of bracketing foundationalist assumptions and embracing 'foundational prudence'. ${ }^{5}$ Since we cannot know which foundationalist claims may be 'true' the best we can do is to get on with our research while isolating any debilitating philosophy of science debates that cannot be authoritatively decided. ${ }^{6}$ However, this move still rests on an agnostic attitude towards possibly existing absolute foundations. In principle, it still allows for the possibility of any particular foundationalist claim being 'correct' or 'real' in some deep ontological or axiomatic sense even though that 'knowledge' is inaccessible to our cognitive capacities. $^{7}$ What seems to produce the impasse here is not the search for self-

\footnotetext{
${ }^{3}$ One may rightfully claim here that these three types of foundationalist claims, i.e. ontological, epistemic and axiological, are analytically distinct and do not necessarily amount to the same thing. That said, this paper argues that all three kinds of foundationalism are necessarily interrelated and can be discussed as part of an inescapably political process, the symbolic ordering of society. Laying out the contours of such a political ontology will be the concern of the next section. Thanks to an anonymous reviewer for alerting me to the need to clarify this point.

${ }^{4}$ Entirely indicatively of what is becoming a growing meta-theoretical consensus, see David Lake, "Why "isms" Are Evil: Theory, Epistemology, and Academic Sects as Impediments to Understanding and Progress', International Studies Quarterly, 55, no. 2 (2011): 465-480; on eclecticism, see Rudra Sil and Peter Katzenstein, Beyond Paradigms: Analytic Eclecticism in the Study of World Politics, (London and New York: Palgrave); and on pragmatism, see 'Symposium: Kratochwil's 'Tartu Lecture' and Its Critics', Journal of International Relations and Development, 10, no. 1, (2007) and 'Special Issue: Pragmatism in International Relations', Millennium: Journal of International Studies, 31, no. 3, (2002).

5 Nuno P. Monteiro \& Keven G. Ruby, 'IR and the False Promise of Philosophical Foundations', International Theory, 1, no. 1, (2009): 15-48.

6 For a similar but more nuanced pragmatic attempt to separate 'philosophical ontologies' (ontological claims that can be treated as a wager) from 'scientific ontologies' (methodological practices that govern scientific inquiry) see Patrick T. Jackson, The Conduct of Inquiry in International Relations: philosophy of science and its implications for the study of world politics, (Oxford; New York: Routledge, 2011).

7 In that sense it is not a coincidence but actually a symptom of that specific understanding of foundations, not as necessarily contingent but as cognitively inaccessible, that some of the participants in the International Theory debate on foundations and the possibility of a postfoundationalist IR ended up accusing each other of hidden or unconscious foundationalism. See, for example, how Jackson's (p. 462) critique to Monteiro \& Ruby is that the latter's promise of 'foundational prudence' is favourably skewed towards scientific realism and Monteiro \& Ruby's (p. 502) reply that Jackson's criticisms rest on unacknowledged philosophical foundationalism privileging social constructivism (see Patrick T. Jackson, 'A Faulty Solution to a False(ly characterised) Problem: a comment on Monteiro and Ruby', International Theory, 1, no. 3,
} 
grounding but the understanding of foundations as presence, as an ultimate ground of the political. ${ }^{8}$ Thus, eliminating the quest for foundations or suspending their absolute claim while accepting it as an ontological possibility won't do the trick; what is needed, instead, is an alternative theorising of foundations that would build on the aporia of their own impossibility and necessity without resurrecting the spectres of ultimate foundations that bring closure to the political. That would, in turn, introduce the possibility of a postfoundational politics faithful to the dialectical tension between continuity and change in (international) politics and, thus, programmatically open to the repoliticising possibilities inherent in social life.

Against this backdrop, this paper reads Morgenthau's sophisticated theory of the political against recent post-foundationalist theorisations of the difference between politics and the political. The primary purpose of this juxtaposition is not necessarily to partake in extending 'reflexive realism's' initial scope $^{9}$ by restoring the possibly unexplored critical credentials of its fatherfigure $^{10}$ or resurrecting theoretical missed opportunities. ${ }^{11}$ These tasks have already been taken up by revisionist scholars with a success that is indicative of the growing self-reflexivity in the field of IR and the disintegration of old disciplinary orthodoxies. Yet, while their ambition to 'save' realism from an impoverished repetition of scholarly dogma is refreshing and long-awaited, it by no means makes them immune to specific disciplinary agendas. ${ }^{12}$ In contrast, the main concern of this paper is not necessarily to add to the revisionist disciplinary scholarship on Morgenthau or classical realism but, instead, to recruit Morgenthau's thought as a didactic example both for his achievements and shortcomings in theorising the political. ${ }^{13}$

(2009): 455-465 and P. N. Monteiro \& G. K. Ruby, 'The Promise of Foundational Prudence: a response to our critics', International Theory, 1, no. 3, (2009): 499-512).

${ }^{8}$ Doucet, 'Standing Nowhere(?)', 293

${ }^{9}$ Brent J. Steele, 'Eavesdropping on Honored Ghosts: From Classical to Reflexive Realism', Journal of International Relations and Development, 10, (2007): 293.

${ }^{10}$ Michael Williams, The Realist Tradition and the Limits of International Relations, (Cambridge; New York: Cambridge University Press, 2005); Vibeke Schou Tjalve, Realist Strategies of Republican Peace: Niebuhr, Morgenthau and the politics of patriotic dissent, (New York: Palgrave MacMillan, 2008); Murielle Cozette, 'Reclaiming the critical dimension of realism: Hans J. Morgenthau on the ethics of scholarship', Review of International Studies, 34, (2008): 5-27.

11 William E. Scheuerman, Morgenthau: realism and beyond, (Cambridge: Polity Press, 2009); William E. Scheuerman, 'A Theoretical Missed Opportunity? Hans J. Morgenthau as Critical Realist' in Duncan Bell ed., Political Thought and International Relations: variations on a realist theme, (Oxford; New York: Oxford University Press, 2009).

12 Darshan Vigneswaran \& Joel Quirk, 'Past Masters and Modern Inventions: Intellectual History as Critical Theory', International Relations, 24, no. 2, (2010): 125. See also the bold claim recently put forward by Nicolas Guilhot, 'One Discipline, Many Histories' in N. Guilhot ed., The Invention of International Relations Theory, (New York: Columbia University Press, 2011), 6-7, that the revisionist historiography on realism can be seen as the latest reincarnation of liberal sensibilities, 'a new orthodoxy in the making' by 'unrepentant idealists' providing 'perfect justification for a policy of selective and limited interventionism' to a declining empire. Guilhot's claim may sound over-stretched but his point that rehabilitated realism should be situated within specific social, political and disciplinary contexts is well taken.

${ }^{13}$ In this respect, this paper treats Morgenthau's work as an inspirational starting point and an appropriate 'dialogical' partner to readjust older insights to 'present-day sensitivities, interests, and understandings' (see Richard Ned Lebow, 'Texts, Paradigms and Political Change' in M. C. Williams ed., Realism Reconsidered: the legacy of Hans J. Morgenthau in International Relations, (Oxford: Oxford University Press, 2007), 250-1). See also Brent J. Steele, 'Context and 
Such an exercise presupposes strong affinities between Morgenthau and critical historicist currents in social and political theory, but this would come as a surprise only to those who equate Morgenthau's realism with stasis and conservatism. Indeed, this paper relates his conceptualisation of power with the historical juncture that prompted its emergence, i.e. the retreat of metaphysical certainty and epistemic foundationalism in the context of post-Nietzschean political philosophy. Indeed, it will be shown that Morgenthau emerges as an apparent candidate to discuss the crisis of foundationalism in (international) political thought and the paradox of its necessity and impossibility, not least because Morgenthau is one of those rare thinkers that offers no facile solution to, or redemption from, the existential anxiety caused by the absence of ultimate foundations in late modernity. That said, this paper will argue that, due to its antinomic premises, Morgenthau's tragic vision of politics can still be viewed as stopping a step shorter of its full-blown critical potential. It is not the purpose of this paper, however, to award or withhold credentials of criticality but to recast Morgenthau's theory of the political as a promising but inconclusive attempt towards a post-foundational political ontology in IR. This, eventually, may serve a purpose far broader than restoring classical realism's latent reflexivity; it may alert us to the conditions and challenges involved in practicing international theory as a constant critique of depoliticisation.

\section{The impasse of foundationalism and the difference between politics and the political}

This section argues for a reconceptualisation of the problem of foundationalism to allow for a sustainably critical engagement with its political nature. If, as noted in the introduction, we cannot step out of the foundationalist discourse without reproducing the terms of our enslavement to it, we could undermine the conditions of our attachment to it from within. Instead of resurrecting the spectres of foundationalism by assuming the absence of any ground, a more successful option would involve denying the existence of an ultimate ground. This move would serve a double purpose: it would open the conceptual space to think the possibility of many grounds; yet, it would do so without reverting to some nihilistic postmodern caricature of pluralism according to which all solid foundations have melt into air and therefore meaning has lost its diacritic capacity.

In his recent study of post-foundational political thought, Oliver Marchart puts forward a vision of political ontology that attempts to come to terms with such a sensibility. ${ }^{14}$ Drawing on a host of post-Heideggerian thinkers, such as Lefort, Badiou, Nancy and Laclau, he relates the retreat of foundationalism in late modernity to the distinction, made by many prominent Anglo-American and continental thinkers, between politics and the political. ${ }^{15}$ Marchart thinks we

\footnotetext{
Appropriation: the risks, benefits and challenges of reinterpretive expression', International Politics, advance online publication, 20 September 2013, doi:10.1057/ip.2013.40.

14 Oliver Marchart, Post-Foundational Political Thought: political difference in Nancy, Lefort, Badiou and Laclau, (Edinburgh: Edinburgh University Press, 2007).

15 See, indicatively, Carl Schmitt, The Concept of the Political, trans. G. Schwab, (Chicago: University of Chicago Press, 1996[1932]); Sheldon Wolin, Politics and Vision: continuity and innovation in western political thought, (Princeton N.J.: Princeton University Press, 2004[1960]);
} 
should treat this distinction as symptomatic of the crisis of foundationalism in late modernity. The post-foundationalist thinkers he systematises, however, do not deny the inescapability of the ground; their post-foundationalism only undermines the absolutisation of notions such as totality, universality, essence, and ground. In that sense, they consciously set themselves apart from vulgar forms of anti-foundationalism or postmodern relativism which tend to regress to a mirror image of the same totalising gesture of foundationalism. Ultimately, this kind of post-foundationalism does not seek to erase foundations, only to inaugurate an ethos of constant interrogation of metaphysical pretensions to foundations and weaken their ontological status. ${ }^{16}$

Hence, a post-foundationalist political ontology 17 of the sorts argued by Marchart would not deny that foundations still exist and perform their functional role but what has been achieved is the acknowledgement that their ontological status is necessarily contingent. As Marchart argues, the argument that the absence of an ultimate ground does not necessarily entail the elimination of the process of grounding can be traced back to Martin Heidegger's conceptualisation of the ground as an abyss ('Der Ab-grund ist Ab-grund'), that is, as a groundless ground. ${ }^{18}$ Heidegger does not understand the place of the absent ground as empty in the ordinary or commonsensical understanding of the term. Since the ground, for Heidegger, is necessarily abyssal, it is precisely by remaining empty by incessantly deferring its own fulfillment- that it remains always open, endlessly generating new possibilities of grounding. The two possibilities of ground and abyss have to be differentiated in some way but they can never be separated neatly as they ceaselessly contaminate each other. In that way, Heidegger allows for both the non-identity of the two terms that is generative of the process of grounding and the inseparable mutual entanglement of ground and abyss that accounts for the paradoxical effect of the same process of grounding/de-grounding.

The generative matrix of this paradoxical effect, for Heidegger, is the difference between the ontological and the ontic level (ontological difference) as such. To ask the grounding question, for Heidegger, is to think through the

Hannah Arendt, Between Past and Future: eight exercises in political thought, (New York: Viking Press, 1968); Philip Lacoue-Labarthe \& Jean-Luc Nancy, Retreating the Political, trans. S. Sparks, (London: Routledge, 1997); Claude Lefort, The Political Forms of Modern Society: Bureaucracy, Democracy, Totalitarianism, (Cambridge, UK: Polity Press, 1986); Chantal Mouffe, On the Political, (New York: Routledge, 2005); Jenny Edkins, Post-structuralism and International Relations: Bringing the Political Back In, (London: Lynne Rienner, 1999); Yannis Stavrakakis, Lacan and the Political, (London: Routledge, 1999); Richard Beardsworth, Derrida and the Political, (New York: Routledge, 1996).

16 Marchart, Post-Foundational Political Thought, 2; see also Beardsworth, Derrida and the Political, xiii, for a similar reference to a body of mainly French political philosophy that engages the question of the constitution of political community as a process of grounding that produces its own unsettling excess.

17 As it will become clear from the subsequent analysis, the use of the term 'ontology' here is predicated on a Heideggerian re-articulation of ontology that challenges traditional metaphysics. In that sense, Heidegger's thought could also be labelled pre-ontological as Heidegger himself puts it: "Being-ontological' is not yet tantamount to 'developing an ontology'. So if we should reserve the term 'ontology' for that theoretical inquiry which is explicitly devoted to the meaning of entities, then what we have in mind in speaking of Dasein's 'Being-ontological' is to be designated as something "pre-ontological" (see Martin Heidegger, Being and Time, trans. J. Macquarrie \& E. Robinson, (Oxford: Blackwell Publishing, 1978), 32).

18 See Marchart, Post-Foundational Political Thought, 18-22. 
problem of grounding under conditions of an abyssal ground and at the same time, to rethink the ontological difference from the perspective of difference qua difference. The play between being qua Being and beings should be thought not in terms of an ontic difference between the two but as the very happening (the unconcealment) of the difference between beings and being as difference. As a result, a space of freedom opens up whose very condition is the negativity, the emptiness, the very absence of ground on which it rests. As put by Oliver Marchart:

The ontological level cannot be accessed immediately, for this would require envisaging it as a solid ground (as being). If it is to fulfill its function of grounding, however, the ground, as we have seen, is simultaneously an a-byss...it is precisely because we cannot access the ontological level directly that -if we want to approach it at all- we will have necessarily to pass through the ontic level, in order to 'wave' at something which will always escape our grasp because of the irremediable gap between the ontological and the ontic, beingness and beings, the ground and what is grounded. ${ }^{19}$

The assumption of a ground which is present in its absence and visible only through the effects it produces eventually paves the way for the possibility of multiple groundings on the ontic level. In fact, the possibility for grounds in the plural is an effect of the impossibility of a present, singular ground (ground as abyss). If this is true, then the contingency of this process of grounding is not accidental but necessary.

Against this backdrop, Marchart finds in post-foundational political thought the conceptual tools to theorise this experience of dislocation in politics that he calls the moment of the political as opposed to politics. The former designates the 'moment of openness, of undecidability when the very structuring principle of society, the fundamental form of the social pact is called into question' whereas the latter describes the positively determined outcome of that process, a 'subsystem of social relations in interaction with other sub-systems'. ${ }^{20}$ He goes even further to suggest that the concept of the political can also be seen as the constitutive way of talking about the fundamental contingency that conditions our engagement in the world, ${ }^{21}$ a sign of temporalisation that keeps open possible processes of politicisation which otherwise, in a society that imagines itself as based on firm and unshakable foundations, could not be envisaged. The difference as such between politics and the political also implies that any effort to cancel this gap or gloss it over by using ethical, political, juridical or economic arguments is nothing else but an attempt to hegemonise the social by ideologically displacing politics. When this happens, the absolute contingency and historicity of the political is either dismissed or forgotten in favour of the fixity of the social. This dialectics between political institution/destitution and social sedimentation is uniquely captured by Ernesto Laclau when he reminds us that sedimented social orders are not non-political

\footnotetext{
19 Ibid, 24.

20 Slavoj Žižek, For They Know Not What They Do: enjoyment as a political factor, $2^{\text {nd }}$ ed., (London and New York: Verso, 2002), 193. See also Beardsworth, Derrida and the Political; Edkins, Poststructuralism and International Relations and Chantal Mouffe, On the Political, (London: Routledge, 2005) for an elaboration on this distinction.

21 Marchart, Post-Foundational Political Thought, 58.
} 
but political albeit in hibernation. ${ }^{22}$ That is, their original political roots -the grounding moment of institution that is called 'the political'- have been forgotten or suppressed within the social but can be reactivated at any time through dislocation and antagonism.

The ideological displacement of politics in which the radical implications of political difference can be disavowed may take many forms. More often than not, the focus of traditional political philosophy or what has been later called normative political theory has been the establishment or legitimation of a 'good order' that would render any form of conflict or antagonism irrelevant. ${ }^{23}$ Jacques Rancière has provided a description of different forms of depoliticisation within political thought. He describes them as 'arch-politics', 'para-politics' and 'metapolitics'. ${ }^{24}$ Slavoj Žižek adds two more, the concepts of 'ultra-politics' and of 'post-politics' (derived from what Rancière calls 'post-democracy'). ${ }^{25}$ For our purposes, the latter two concepts employed by Žižek designate what an ideological displacement of politics amounts to by way of either reducing the political to politics or hypostasising the political directly into politics. The former case signals the familiar post-political foreclosure of the ontological instance of antagonism. The very existence of constitutive contestation at the heart of the social is denied; society is imagined not as an impossible achievement but as a world without conflict, where consensus is already established (Rawlsian liberalism) or is to be established in the long run (deliberative democracy). In the case of ultra-politics, the political (as the ontological instance of antagonism) assumes full domination over politics. The political adversary is seen as an enemy to be destroyed by all means. Once more the difference between politics and the political collapses, this time on the side of the political which politics is supposed to enact in an immediate way. The ontological ground/abyss appears directly into the ontic realm with often catastrophic effects (total war, revolutionary terror). ${ }^{26}$

Yet, the fact that everything is political does not mean that politics or the political reside in all beings in an immediate way. A world where social ontology would not be mediated by the political difference would equal either a world in which politics (in the ontic sense) has infiltrated all corners of the social or a world in which the political (in the ontological sense of antagonism) is fully enacted on the entire scale of the social. Yet, this latter possibility is a peculiar instance which nobody has ever witnessed. As we have already mentioned, the presence of the political as the ontological moment of society's institution can only be inferred from the absence of a firm ground of society, from our experience of the incompletion of the realm of social beings. The moment of the political, when society confronts its own contingent origins and the necessity to institute temporary grounds, has always already come and does not stop existing as an endlessly lurking possibility; yet, nobody has ever seen the realm of the

\footnotetext{
22 Laclau, New Reflections On the Revolution of Our Time

${ }^{23}$ Chantal Mouffe, The Return of the Political, (London: Verso, 1993).

${ }^{24}$ Jacques Rancière, Disagreement: politics and philosophy, (Minneapolis: University of Minnesota Press, 1999).

${ }^{25}$ Slavoj Žižek, The Ticklish Subject: The Absent Centre of Political Ontology, (London and New York: Verso, 1999).

${ }^{26}$ See Chantal Mouffe, The Return of the Political, (London; New York: Verso, 1993) and Chantal Mouffe, On the Political, (Abingdon; New York: Routledge, 2005).
} 
'onto-political' as such, except in the cracks and fissures of the social which politics is always trying to foreclose but constantly fails to do. ${ }^{27}$ Politics is incessantly trying to get hold of the political but we are each time painfully reminded that an unbridgeable chasm separates the two. It is exactly the irresolvability of this gap that makes politics the name for a paradoxical enterprise which is both impossible and inevitable -which is why none has ever witnessed 'pure politics' either. The political cannot be brought about voluntaristically but, whenever we act, it is as if we always activate it or, better, we are always enacted by it. ${ }^{28}$

This is why every displacement of politics -whether it contains the foreclosure of society's ungroundable nature by collapsing the political into politics or politics into the political- is a manifestation of the political in itself. The denegation of society's groundless nature may occur either in a foundationalist or an anti-foundationalist way; either by affirming an ultimate ground or denying the possibility of grounding altogether and transposing the necessity of contingency from the realm of the political into that of politics; in other words, hypostasising the onto-political in an immediate way. Both gestures end up abolishing the political difference and ultimately result in an ideological displacement of politics. Morgenthau's intellectual genius and integrity consists in both recognising those forces at play in the political and refusing to gloss over the logic of antagonism that permeates international politics. In the next section, I will argue that by equally shunning a facile surrender either to the immanence of power (ultra-politics) or to the technologisation of politics (post-politics), Morgenthau's theory of the political strove to maintain fidelity to the logic of political difference as such.

\section{'Lifting the veil of anonymity': Morgenthau's theory of the political as critique of depoliticisation}

It is often argued that the difficulty in comprehending Morgenthau's view of the political lies in the apparent contradiction between his Nietzschean radical skepticism and his Weberian ideal-type categorisations. ${ }^{29}$ On the one hand, he seems to subscribe to Nietzsche's primary diagnosis of modernity after the 'death of God' interpreted as the disintegration of an international moral realm 'composed of Christian cosmopolitan and humanitarian elements'. ${ }^{30}$ In fact, for Morgenthau, disenchantment is not exclusively a moral crisis but a crisis of epistemic orientation as well. The ability to rationally discover a strong, singular meaning of the world -an ultimate foundation- is irretrievably lost and men must learn to 'meet under an empty sky from which the gods have departed'. ${ }^{31}$ It is worth noting that this situation is not necessarily a deplorable state of affairs, for

\footnotetext{
27 Marchart, Post-Foundational Political Thought, 174.

28 See Marc De Kesel, 'Act Without Denial: Slavoj Žižek on Totalitarianism, Revolution and Political Act', Studies in East European Thought, 56, (2004): 299-334.

29 Sean Molloy, The Hidden History of Realism: A Genealogy of Power Politics, (Basingstoke: Palgrave Macmillan, 2006), 76; see also H-K. Pichler, 'The godfather of 'truth': Max Weber and Carl Schmitt in Morgenthau's theory of power politics', Review of International Studies, 24, (1998): 185-200.

${ }^{30}$ Hans J. Morgenthau, Politics Among Nations: The Struggle for Power and Peace, $4^{\text {th }}$ Edition (New York: Alfred A. Knopf, 1967), 244.

31 Ibid, 249.
} 
Morgenthau, as the ensuing indeterminacy and uncertainty may be seen as an opportunity for man to rediscover and re-employ his creative potentialities. ${ }^{32} \mathrm{On}$ the other hand, however, he seems to evoke some kind of foundationalist sensibility when, in his six principles of political realism, he postulates that 'international politics like all politics is a struggle for power, and that 'politics, like society in general, is governed by objective laws that have their roots in human nature'. ${ }^{33}$ How are we to interpret this apparent resort to determinism, this immediate closure imposed on an inherently open situation? First of all, is it really a closure dictated perhaps by the demands of writing a polemic ${ }^{34}$-or perhaps a textbook ${ }^{35}$ - or does Morgenthau allude to something else? Has he seen the abyss of indeterminacy, suffered the vertigo and shirked from the devastating consequences of embracing nihilism or is there something deeper going on?

Compounded by Morgenthau's own ambiguity, interpretations on this issue abound. On the one hand, an array of serious critics have derided Morgenthau's preoccupation with identifying the 'objective laws' of international politics as a concession to positivism ${ }^{36}$ or charged him with fetishisation of the national interest. ${ }^{37}$ On the other hand, scholars such as Murielle Cozette, Michael Williams and William Scheuerman, tend to see him more or less as a protoCritical theorist tragically misunderstood by his intellectual descendants as advocating a value-free international politics where power considerations reign supreme and moral aspirations are a costly luxury. ${ }^{38}$ Hence, Cozette portrays Morgenthau as a neglected critical scholar who was determined to speak truth to power 'by permanently reminding Power that it lies when it pretends to embody Truth or Justice'. ${ }^{39}$ This is, admittedly, far from an unfair depiction since realism as a tool of unmasking moralism as a self-serving ideology has a long pedigree. Robert Cox and Richard Ashley were among the first to notice realism's affinities with the hermeneutics of suspicion. ${ }^{40}$ This reluctance to take beautiful ideas at

\footnotetext{
32 Mihaela Neacsu, Hans J. Morgenthau's Theory of International Politics: Disenchantment and ReEnchantment, (Basingstoke: Palgrave Macmillan, 2010), 53.

${ }^{33}$ Hans J. Morgenthau, Politics Among Nations, 4.

${ }^{34}$ David Fromkin, 'Remembering Hans Morgenthau', World Policy Journal, 10, no. 3, (1993): 84.

35 Jonathan Cristol, 'Morgenthau vs. Morgenthau? "The Six Principles of Political Realism" in Context', American Foreign Policy Interests, 31, no. 4, (2009): 238-244.

36 Justin Rosenberg, 'What's the matter with realism', Review of International Studies, 16, no.4, (1990): 285-303; Jim George, Discourse of Global Politics: a critical (re)introduction to international relations (Boulder, Colo: Lynne Rinner, 1994); Martin Griffiths, Realism, Idealism and International Politics: a reinterpretation, (London; NY: Routledge, 1992); Martin Hollis \& Steve Smith, Explaining and Understanding International Relations, (Oxford: Clarendon Press, 1991).

37 Veronique Pin-Fat, 'The Metaphysics of the National Interest and the Mysticism of the NationState: reading Hans J. Morgenthau', Review of International Studies, 31, (2005): 217-236.

38 Cozette, 'Reclaiming the critical dimension of realism'; Michael Williams ed., Realism Reconsidered: the legacy of Hans Morgenthau in international relations, (Oxford; New York: Oxford University Press, 2007); Michael Williams, The Realist Tradition; Michael Williams, 'Why Ideas Matter in International Relations: Hans Morgenthau, Classical Realism, and the Moral Construction of Politics', International Organization, 58, no. 4, (2004): 633-665; William E. Scheuerman, Morgenthau: realism and beyond; William E. Scheuerman, 'A Theoretical Missed Opportunity?'.

${ }^{39}$ Cozette, 'Reclaiming the critical dimension of realism', 10.

40 Robert Cox, 'Social Forces, States and World Orders: Beyond International Relations Theory', Millennium: Journal of International Studies, 10, no. 2, (1981): 126-155; Richard K. Ashley,
} 
face value coupled with a commitment to unveiling the ideological use of such ideas as self-evident truths lies behind the critical function of what Guzzini calls 'anti-apparent realism'. ${ }^{41}$

Indeed, most of the new wave of interpretations of Morgenthau's complex realism agree that not only can he not be readily dismissed as a thorough-going Machiavellian ${ }^{42}$ but that his outlook on politics share family resemblances with themes that have been traditional concerns of critical (international) political theory and normative IR. ${ }^{43}$ Williams invites us to discover the Morgenthau who grappled with the fundamental paradox of politics in modernity after Nietzsche. For Williams, Morgenthau sensed that, if after the dissolution of ultimate foundations a descent to relativistic nihilism and a vision of politics as the crude exercise of naked power were to be averted, the negation of power's necessity would not do. Instead, a constructive engagement with its pervasiveness was urgently needed. Hence, his urge to view the indeterminacy of politics as a potentially positive phenomenon, representing the possibility of change, and as a core principle of democracy'. ${ }^{4}$ Petersen goes even further in claiming that Morgenthau shouldn't even be included among the contemporary realist gambit as his conception of the relationship between man and the world is far too complex to merit reduction to static views on human nature or pshychologism. ${ }^{45}$

Most relevantly for our purposes, Scheuerman demonstrates how one of Morgenthau's major works Scientific Man vs. Power Politics promotes an autonomous and specific understanding of politics according to which the special attributes of political action and public engagement should be defended against the depoliticising effects of modern modes of economic, social and administrative organisation. ${ }^{46}$ Following Weber, Morgenthau criticised the antipolitical contours of modern thought as well as the legalistic and rationalistic excesses of contemporary liberalism. In fact, since his early critique of legal positivism in Weimar Germany and his exhortations for a sociology of law, 47 Morgenthau was struck by the 'general decay of political thinking in the Western world' and the total neglect for the fundamental questions of human existence which he, following Carl Schmitt, attributed to the bleak obfuscation of the autonomy and specificity of the political imposed by modern scientism and liberalism.

In this respect, Morgenthau can be placed along the lines of a number of intellectuals deeply concerned with the eclipse of the political in modern liberal,

'Political Realism and Human Interests', International Studies Quarterly, 25, no. 2, (1981): 204236.

${ }^{41}$ Stefano Guzzini, 'The Enduring Dilemmas of Realism in International Relations', European Journal of International Relations, 10, no. 4, (2004): 553.

${ }^{42}$ See Benjamin Wong, 'Hans Morgenthau's Anti-Machiavellian Machiavellianism', Millennium: Journal of International Studies, 29, no. 2, (2000): 389-409.

43 Richard Ned Lebow, The Tragic Vision of Politics: Ethics, Interests, Orders, (Cambridge: Cambridge University Press, 2003); Hartmut Behr and Felix Rösch, 'Introduction' in Hans J. Morgenthau, The Concept of The Political, trans. Maeva Vidal, (Basingstoke; New York: Palgrave MacMillan, 2012), 22-32.

${ }^{44}$ Williams, The Realist Tradition, 116.

${ }^{45}$ See Ulrich-Enemark Petersen, 'Breathing Nietzsche's Air: New Reflections on Morgenthau's Concepts of Power and Human Nature', Alternatives, 24, no. 1, (1999): 83-118.

${ }^{46}$ Scheuerman, Morgenthau: realism and beyond, 44-45.

${ }^{47}$ See William E. Scheuerman, 'Realism and the Left: the case of Hans J. Morgenthau', Review of International Studies, 34, (2008): 29-51. 
post-political, administrative societies. Morgenthau's intellectual stance was triggered by the failure of Weimar Germany to avoid the double danger of either sliding into a complete disregard of the power realities of politics or embracing a totalitarian form of 'pure politics' utterly unrestrained by necessary normative limitations on political action. In the language of this paper, Morgenthau issued a warning against the swallowing up of the political either in the form of a postpolitical, non-antagonistic liberalism with illusions of a harmonistic social and political order or in the guise of an ultra-political adoration of pure power politics most vividly witnessed in fascism and, post-World War II, in the politics of nuclear escalation. ${ }^{48}$

This situation of social, political and, after the Great Depression, economic malaise was also described in different terms by E. H. Carr in his Twenty Years' Crisis, but the two archetypical IR figures were not alone in observing these alarming tendencies nor were they the first to attribute them to the instrumentalisation of politics in the twentieth century. ${ }^{49}$ Carl Schmitt was among the first who noticed that political violence and extremism was not an effect of politics invading all levels of society but, paradoxically, a result of the retreat of politics and the loss of its specificity and relative autonomy. The challenge, for Schmitt, consisted in 'discovering... specifically political categories' and thus the identification of specific criteria that would enable the tracing of 'all actions with a specifically political meaning'. ${ }^{50}$ His answer was the famous friend-enemy distinction that went beyond the 'proceduralism' of the market model instituted by liberal politics to reinstate an existential category of antagonism. This distinction constituting the 'concept of the political' is not a normative category within politics (in other words, it is not solely one social domain among others) but the concrete form of accounting for an autonomous identity of the field of politics that is acknowledged a privileged position by being 'the strongest and most intense of the distinctions and categorizations'. 51 Thus, not only a relative autonomy and specificity but also a certain primacy has to be

\footnotetext{
${ }^{48}$ Hans J. Morgenthau 'Death in the Nuclear Age,' Commentary, 32, (1961): 231-234. According to Fromkin, 'Remembering Hans Morgenthau', 86, the question of the progressive eclipse of political rationality consumed Morgenthau in his later years and prompted him to insert new paragraphs in his magnum opus, Politics Among Nations, suggesting the need for a theory of international misunderstanding, that is, a theory of irrational international politics or in his words 'a kind of pathology of international politics'.

${ }^{49}$ Nor the last, see Theodor W. Adorno \& Max Horkheimer, Dialectic of Enlightenment, trans. J. Cumming, (London: Verso, 1997[1947]).

50 Schmitt, The Concept of the Political, 22-26.

51 Ibid, 27. The laurels for this addition to Schmitt's concept of the political to include the dimension of intensity belong to Morgenthau who in his 1929 doctoral dissertation, entitled Die internationale Rechtspflege: Ihr Wesen und ihre Grenzen, had developed his own notion of the political in critical conversation with Schmitt as 'a quality, a tone' -not a substance- capable of infiltrating every aspect of international life (see Morgenthau, The Concept of the Political, 101-2). All this is well documented in William E. Scheuerman, Carl Schmitt: The End of Law, (Lanham, MD, Boulder, Oxford and New York: Rowman \& Littlefield, 1999), 225-237 and Marti Koskenniemi, The Gentle Civilizer of Nations: The rise and fall of international law 1870-1960, (Cambridge: Cambridge University Press, 2001), 436 along with Schmitt's reluctance to acknowledge Morgenthau's contribution to the former's revision of his concept of the political, hence the title of this section 'lifting the veil of anonymity'. The importance of Morgenthau's addition lies in the fact that the political assumes not only autonomy and specificity but primacy as well since any other social domain is nothing but political in the waiting or in the sleeping mode revealing its political nature when antagonism is intensified.
} 
accorded to the political: 'every religious, moral, economic, ethical, or other antithesis transforms into a political one if it is sufficiently strong to group human beings according to friend and enemy'. ${ }^{52}$

Schmitt's purpose in making the friend/enemy distinction central to the political was to resist the domestication of political antagonism inherent in liberalism. For Schmitt, the primacy of the political is not a triumphant actuality but an endangered possibility, always at risk of becoming colonised by the iron cage' of a bureaucratised, technologised and depoliticised society. ${ }^{53}$ Morgenthau shared this Schmittian motif as his critique of scientism in Scientific Man vs. Power Politics amply exemplifies. ${ }^{54}$ Yet, while the two share the diagnostic part of the critique of liberalism and scientism, they crucially depart ways in the analysis of the origin of the fundamental antagonism that pervades the social. Schmitt eventually locates the roots of political intensity in the inherent evilness and aggressivity of human nature. Contrarily, Morgenthau believes that this is an impoverishment and distortion of the roots of political conflict which should be grounded on the complex interrelation of psychological and empirical factors rather than on the metaphysics of a fixed human nature. 55

Indeed, Schmitt's metaphysical reduction of the political to the friend/foe distinction, apart from striking as tautological and arbitrary, ${ }^{56}$ had radical implications that Morgenthau sought to avoid such as the romanticisation of an existential decisionism and the sublimation of brute force grounded on a pessimistic anthropology. To be sure, Morgenthau grounds his agonistic view of politics on 'the lust for power which is common to all men'57 from which critics, perhaps understandably, infer that he endorses a metaphysical grounding of human motivation. Morgenthau's close association of human nature and political antagonism, however, may be ontological but is far from metaphysical. Petersen is a good guide here in disentangling this vexed issue. The lust for power in Morgenthau is not a metaphysical principle denoting some fixed human inclination towards conflictuality. Instead, '[i]t is a principle that transcends and thus dismantles the modern concept of self, and as such it takes us beyond motives and desires. In its most fundamental sense it is an attempt to explain how consciousness and reasoning are in themselves made possible.'58 Morgenthau is effectively reminding us that human beings' search for meaning in the world (the moment of self-consciousness) is born in struggle against an ontological horizon that precedes subjectivity, a horizon that has to be subdued to beget meaning but keeps coming back as a haunting spectre.

Here Morgenthau's all-encompassing conception of power and ontological understanding of politics come interestingly close to the anti-essentialist character of political difference. On the one hand, by defending the all-

\footnotetext{
52 Schmitt, The Concept of the Political, 37.

53 Carl Schmitt, 'The Age of Neutralizations and Depoliticizations', Telos: A Quarterly Journal of Critical Thought, 96 (summer 1993): 138.

${ }^{54}$ Hans J. Morgenthau, Scientific Man Vs. Power Politics, (Chicago: University of Chicago Press, 1946)

55 Morgenthau, The Concept of the Political, 99, where he insists that the political nature of things 'depends on circumstances of time and place and does not result from a ground of principle'. See also Scheuerman, Carl Schmitt: The End of Law, 239-40.

${ }^{56}$ Morgenthau, The Concept of the Political, 108.

57 Morgenthau, Scientific Man Vs. Power Politics, 5.

58 Petersen, 'Breathing Nietzsche's Air', 99.
} 
pervasiveness of power -which, for Morgenthau and a long tradition of thought that harks back to Augustine, is the twin of a frustrated relationship of love- ${ }^{59}$ he describes the principle of antagonism that pervades social existence and accounts for both the destructive and the constructive potentialities of human agency. Politics without power is, for Morgenthau, unthinkable. But power, for him, is not a metaphysical abstraction derived out of a fixed view about human nature as inherently evil $\grave{a}$ la Schmitt; rather, it signifies the force of the political as the various forms, conflictual or irenic, human interaction takes in constructing different spatio-temporal configurations of the social. ${ }^{60}$ In this process, politics without the political becomes the deracinated administration of things. By adding to the Schmittian autonomy and specificity of the political the primacy of power as the ultimate reality and truth of international politics, Morgenthau institutes an understanding of the political as fidelity to antagonism ${ }^{61}$ expressed in the form of a tension between man's inability to ground his own being in a post-Nietzschean world and the need to incessantly engage with meaning construction in a world that defies absolute grounding.

Yet, the political (human beings' power drive carrying both creative and destructive capacities) without politics (value conflicts over the authoritative ordering of the social) leads to a different kind of depoliticisation, that of politics without transcendence, or else, of surrendering oneself to the immanence of power. ${ }^{62}$ Employing the metaphor of tragedy, Morgenthau admits that humans cannot easily dispense with the search for ultimate foundations as a way of giving meaning to their existence despite the absolute futility of the task. Indeed, human beings, for Morgenthau, are tragic subjects because they are torn between the necessity and the impossibility of acting ethically. The language he uses to express this sensibility is that of a transcendent but no longer 'objective' morality that Petersen beautifully describes as a 'Kantianism without redemption, a simultaneous projection of freedom and necessity that turns the latter's ethical philosophy into an overarching antinomy whose continuous negotiation is the

\footnotetext{
${ }^{59}$ Hans J. Morgenthau, 'Love and Power', Commentary, 33, (1962): 249.

${ }^{60}$ See Felix Rösch, 'The Human Condition of Politics: considering the legacy of Hans Morgenthau for international relations', Journal of International Political Theory, 9, no.1, (2013): 1-21.

61 'Political realism is aware of the moral significance of political action. It is also aware of the ineluctable tension between the moral command and the requirements of successful political action. And it is unwilling to gloss over and obliterate that tension (emphasis added)... by making it appear as if the stark facts of politics were morally more satisfying than they actually are, and the moral law less exacting than it actually is.' (Morgenthau, Politics Among Nations, 10)

${ }^{62}$ Hans J. Morgenthau, 'Another 'Great Debate': The National Interest of the United States' The American Political Science Review, XLVI (December, 1952), 987: "To say that a political action has no moral purpose is absurd; for political action can be defined as an attempt to realize moral values through the medium of politics, that is, power." Behr and Rösch, 'Introduction', 52-64 make a distinction between Morgenthau's empirical (pouvoir) and normative (puissance) conception of power. They correctly point out that Morgenthau's distinction reflects his opposition to depoliticised forms of power that restrict the human creative capacity for building meaningful spatio-temporal articulations of the common good. See also Felix Rösch, 'Pouvoir, puissance, and politics: Hans Morgenthau's dualistic concept of power?', Review of International Studies, 39, (2013). However, according to the logic of political difference expressed in this paper, Morgenthau's animus dominandi is not strictly speaking 'empirical' as human beings' power drive can be good or bad, creative or destructive. In that sense, a distinction relevant to this paper would be that of an 'ideologised' or 'depoliticised' (pouvoir) as opposed to a 'critical' or 'reflexive' (puissance) concept of power.
} 
stuff of human life'. ${ }^{63}$ Human beings are both political and moral creatures and come up against circumstances where politics and morality make contradictory claims on them. ${ }^{64}$

This part of Morgenthau's legacy has been often interpreted as most promising as it refuses to gloss over the indeterminacy inherent in the operation of politics and succumb to a premature closure of the political. ${ }^{65}$ Petersen, for example, cites Morgenthau's tragic sensibility as a corrective to those who have the tendency 'to resort to rhetorical sleights of hand that amount to little more than statements of intent masquerading as solutions to an intractable, and in Morgenthau's opinion probably insoluble, problem.'66 Whatever his personal predilections or moral convictions, Morgenthau refused to relax the tension between human beings as free moral agents and a less than perfect political reality, somehow always falling short of our best intentions. ${ }^{67}$ Moreover, his acceptance of the possibility of unintended consequences and his emphasis on concrete, standortgebunden ${ }^{68}$ analysis and the necessity of exercising prudence and judgement in moral dilemmas all attest to his constant struggle with the challenge of temporality, contingency and historicity. In his socio-political analysis, Morgenthau uses concepts such as 'power' and 'interest' as ideal types that indicate the possibility of making human conduct intelligible, and to an extent predictable, in a world that is in constant flux and marked by multiple contingencies, not least of which necessarily arise from the conflicting value choices various agents make. ${ }^{69}$

\footnotetext{
${ }^{63}$ Petersen, 'Breathing Nietzsche's Air', 107. Morgenthau displayed a characteristic reticence to close the gap between politics and morality. His scepticism does not necessarily deny the objectivity of values (which for him consist in a mix of Kantian and Judeo-Christian morality) but the possibility of grounding them in uncontested metaphysical moorings. The preservation of 'timeless ethical values' becomes for him a prophetic task, the 'moral mission of mindful human beings' (see Christoph Frei, Hans J. Morgenthau: An Intellectual Biography, (Baton Rouge: Louisiana State University Press, 176).

${ }^{64}$ Hans J. Morgenthau, 'The Evil of Politics and the Ethics of Evil', Ethics, 56, no. 1, (1945): 1-18.

65 See Williams, 'Why Ideas Matter in International Relations', 649 and Vibeke Schou Tjalve, 'Realism and the Politics of (Dis)Enchantment' in Bell ed., Political Thought and International Relations, 183. For an argument that 'grounds' this indeterminacy on Morgenthau's understanding of the self as constitutively incomplete, see Ty Solomon, 'Human Nature and the Limits of the Self: Hans Morgenthau on Love and Power', International Studies Review, 14, (2012), 219-20.

${ }^{66}$ Petersen, 'Breathing Nietzsche's Air', 111.

${ }^{67}$ Alistair H. J. Murray, 'The Moral Politics of Hans Morgenthau', The Review of Politics, 58, no. 1, (1996): 92, 97.

68 The use of this term is influenced by Karl Mannheim's sociology of knowledge and designates the historically determined, and thus contingent, nature of all social and political thought. Morgenthau did not intend his realism to serve as a rigid epistemology, a supra-historical structure of explanation divorced from historical and practical exigencies (see his 'The State of Political Science', Dilemmas of Politics, (Chicago: University of Chicago Press, 1958). On the contrary, his emphasis on the normative dimension of action and his critique of the dangerous ideology of a particular historical constellation, that of the $19^{\text {th }}$ and $20^{\text {th }}$ century world of nationstates, attests for his view of scholarship as an inevitable and on-going confrontation with temporality and contingency (see also Hartmut Behr \& Amelia Heath, 'Misreading in IR theory and Ideology Critique: Morgenthau, Waltz and Neo-realism', Review of International Studies, 35, (2009): 336).

${ }^{69}$ See S. Turner, \& G. Mazur, 'Morgenthau as a Weberian Methodologist', European Journal of International Relations, 15, no. 3, (2009): 477-504. For a view that Morgenthau's idea of social scientific objectivity is more Nietzschean than Weberian, see Behr and Rösch, 'Introduction', 43.
} 
In no way, however, does Morgenthau succumb to an understanding of those ideal types as corresponding to any deep essence or unified logic of reality, as he is often misunderstood by those who brand him a positivist. Morgenthau's interplay between our understanding of the rational order of things and a recalcitrant reality remains a semeiotic, ${ }^{70}$ a distinctively hermeneutic exercise strikingly evoking the impossibility of the political to appear as such and the constantly displaced claim of politics to represent it. Equally, in his moral discourse Morgenthau insists on the necessary impurity of the moral act that produces a peculiar kind of political ethics with a critical edge. His ethics of lesser evil reflects uneasiness with moral intransigence or lack of concreteness in ethical judgement. ${ }^{11}$ In obvious homology with the necessarily mediated (but never reducible to politics) nature of the political, morality exists but never in isolation from its concrete political predicament.

\section{Beyond Morgenthau: post-foundational political ontology and the re-making of International Relations theory}

As we have already established, Morgenthau viewed political action as inherently contradictory, something that human beings are condemned to do since acting politically is a self-constituting activity through which they establish a meaningful interpretation of the world and of themselves but also an activity that is doomed to fail as it constantly falls short of the complexity of human existence, i.e. 'the riddles of the world and of his existence on the other'. ${ }^{72}$ On the one hand, Morgenthau's concept of the political resembling the Nietzschean Willto-Power is 'not something that we have but much more profoundly, 'something we are', and politics thus not a choice but an inescapable premise'. ${ }^{73}$ On the other hand, nothing secures us from abusing our powers of self-making and turning the openness offered by the relativist struggle against certainty into an open invitation to indiscriminate violence or unprincipled politics.

Morgenthau, especially during his years in America, ${ }^{74}$ was conscious of the challenge presented and the opportunities offered by this Nietzschean vitalism and the ensuing scepticism. Accordingly, he identified the task lying ahead as how to strike the right balance 'between the dangers of an end to politics on the one hand, and the hazards of rendering politics an absolute end in itself on the other'. ${ }^{75}$ Both contingencies represented what we came to identify in this paper as forms of depoliticisation, i.e. instances of the displacement of the political premised upon the suppression of the ontological dimension of antagonism. Morgenthau came to realise that a reactivation of the political would entail the recognition that politics is about engaging in constantly failed transcendental attempts to ground the social. His understanding of a democratic

\footnotetext{
${ }^{70}$ James Der Derian, 'A Reinterpretation of Realism: Genealogy, Semiology, Dromology' in Der Derian, J. (ed.), International Theory: Critical Investigations, (London: Palgrave, 1995), 368.

${ }^{71}$ See Hans J. Morgenthau, 'The Evil of Politics and the Ethics of Evil', Ethics, 56, no. 1, (1945): 118 and Sean Molloy, 'Aristotle, Epicurus, Morgenthau and the Political Ethics of the Lesser Evil', Journal of International Political Theory, 5, no. 1, (2009): 94-112.

72 Morgenthau, Scientific Man Vs. Power Politics, 206-7.

73 Tjalve, Realist Strategies, 100; see also Petersen, 'Breathing Nietzsche’s Air', 95.

${ }^{74}$ Murielle Cozette, 'What Lies Ahead: Classical Realism on the Future of International Relations', International Studies Review, 10, (2008): 670.

75 Tjalve, Realist Strategies, 97.
} 
community and the critical operation of transcendent ideas such as justice and morality in his work reflect his conviction that transcendent visions are necessary for human beings to unfold their potential. ${ }^{76}$

Morgenthau's thought here seems to attribute to transcendent ideals what in Ernesto Laclau's post-Marxist analysis is described as the operation of 'empty signifiers'. ${ }^{77}$ Empty signifiers, for Laclau, are those signifiers which attempt to represent the absent fullness of a community. That is, they are those signifiers which embody the unity of a community which, nevertheless, cannot ever be fully achieved. Laclau argues that in a situation of radical dislocation of the social fabric in which a need for order arises, people prioritise the need for 'an order' over its actual contents: "order' as such has no content, because it exists only in the various forms in which it is actually realised'. However, in a situation of radical disorder 'order' is 'present as that which is absent; it becomes an empty signifier, the signifier of that absence'. ${ }^{78}$ As a result, political forces may compete in their efforts to present their particular objectives as those which may carry out the task of filling the lack, thus engaging in ideological struggles over the filling out of such empty signifiers. This filling process operates through a double movement. It is a process that simultaneously signifies the need to constitute a unified representation of society, and the impossibility of ever doing so entirely. ${ }^{79}$ Similarly, in Morgenthau, that an ideal transcend us ultimately means that we shall not be able to achieve it. For societies to remain vital, they must 'stimulate the construction of utopian imaginaries while simultaneously recognising that no person has definite access to the content of this'. ${ }^{80}$ This results in the ever-present possibility of recontestation and struggle over the particular objects that may take on this task, a task which is, in principle and in practice, impossible to fulfil.

There are clear parallels between the function and role of the empty signifier and its particular fillers, and that of Morgenthau's inspirational transcendent visions and their filling-out through democratic critique and contestation. Empty signifiers, like Morgenthau's transcendental signifiers, ultimately have no signifieds. They signify a structural impossibility in signification as such, an impossibility that is shown only in the interruption or subversion of the sign. It suggests that in some instances 'justice' may come to represent the 'pure being of the system', a being which is constitutively unrealisable. ${ }^{81}$ We are thus dealing with an impossibility that can only ever be instantiated or 'positivised' approximately. Morgenthau expresses this idea in discriminating between a destructive moral nihilism and a healthy moral scepticism:

[We are] not concerned here with debating the view that justice does not exist and is a mere illusion. Rather, we want to show that, even if assuming the reality

\footnotetext{
${ }^{76}$ Tjalve, 'Realism and the Politics of (Dis)Enchantment', 184-191.

77 Ernesto Laclau, 'Why Do Empty Signifiers Matter to Politics' in Emancipation(s), (London: Verso, 1996).

78 Ibid, 44.

${ }^{79}$ Laclau's emphasis on the impossibility of society and a fully constituted identity draws inspiration from the psychoanalytic and the deconstructive traditions; compare with Derrida, Writing and Difference, 278-93.

80 Tjalve, Realist Strategies, 122.

81 Laclau, 'Why Do Empty Signifiers Matter to Politics', 39.
} 
of justice, we are not capable of realizing it. The two positions are by no means identical. They are no more identical than the atheist position denying the existence of God is identical with the view that man is incapable of knowing God, even if he does exist. 82

Despite its promise, however, the problem with this understanding of the relationship between transcendence and immanence is that it postulates an unbridgeable gap between the two aforementioned dimensions fuelling, in turn, a process of what Hegel called bad infinity. This is more than evident in Morgenthau's wholesale embracement of the Pascalian sensibility that envisages human beings as always stranded between the inexorable determinism of nature and their ability to transcend finitude. ${ }^{83}$ In trying to tread a precarious path between avoiding the reification of either a politics of unending violence or of post-political ratiocination, Morgenthau's 'Kantianism without redemption' remains trapped in the dialectics of bad conscience. That is, I can never be sure that I did the right thing or that I fully assumed my responsibility because, even if I manage to treat someone virtuously or justly, that will always happen at the expense of someone else, my family to the detriment of other families, a stranger to the detriment of other strangers. The programmatic impurity of the ethical act seems to be the fundamental requirement of a truly ethical decision. One, then, is still seized by the despairing ambivalence that something must necessarily escape us when making an ethico-political decision in the face of undecidability. Morgenthau, in a way reminiscent of Laclau's formalism, seems to embrace a similar Kantian (as well as Pascalian and Sophoclean) -by way of reinscribing an antinomy between freedom and necessity- sense of the tragic. ${ }^{84}$ Morgenthau envisages a democratic community as the one in which everything turns around the possibility of keeping always open and ultimately undecided the moment of articulation between the universality of the normative order and the singularity of the ethical moment. Depoliticisation, however, is likely to emerge not only from misrecognising necessity and naturalness where there are only impermanent and contestable social arrangements but also from the temptation to view universality as an empty form always longing to be filled and a priori failing to achieve the reconciliation between a recalcitrant reality and our ethical ideals. $^{85}$

\footnotetext{
82 Hans J. Morgenthau, Truth and Power: Essays of a Decade 1960-1970, New York, Washington, London: Praeger Publishers, 1970), 62-3.

${ }^{83}$ See Morgenthau, Scientific Man Vs. Power Politics, 223.

${ }^{84}$ See Lucien Goldmann, The Hidden God: a study of tragic vision in the Pensées of Pascal and the tragedies of Racine, (London: Routledge \& Kegan Paul, 1964), 15, 48-9. Here there are more than structural similarities between Pascal's wager, Kant's antinomic thinking, Kierkegaard's leap of faith and Morgenthau's theorising under an empty sky where belief in morally transcendent principles is also an act of faith. The point here is not the obvious one, i.e. to place Morgenthau in the line of tragic thinkers that repeatedly failed to reconcile antinomic positions, but to argue that positioning oneself towards that failure (is it a source of despair or renewal?) makes all the difference.

85 In this respect, Morgenthau's reduction of unresolved antinomies to an anthropological transhistorical structure may then explain his lack of clarity in grounding his political ethics and the tendency of his realism to be equated with Heinrich Treitschke's realpolitik. See here Morgenthau's protestations that his work had been misunderstood and him taking the blame for it in a letter to Oakeshott, in Frei, Hans J. Morgenthau, 204.
} 
Ultimately, Morgenthau remains relevant for a critical investigation of depoliticisation in IR not so much in offering an understanding of the limitations surrounding human knowledge and action. Rather, it is because his postfoundational articulation of the political as an unending dialectics of openness and closure enables the re-marking of the critical 'groundless ground' from which the same problems, the same challenges, the same impossible simultaneity of the transcendental and the empirical can be rethought and reproblematised for progressive purposes. ${ }^{86}$ His thought was pregnant with critical insights exactly because, whether he theorised on power, morality, politics or human nature, his pronouncements were marked by a fidelity to negativity and an appreciation of the spatio-temporal contingencies that make up social life. This is more than evident in his persistent refusal to naturalise historically conditioned structures as, for instance, in his discussion of the obsoleteness of the nation state and the possibility of a world-state in Politics Among Nations or in his vehement rejection of perfectionist ethics. In allowing for the possibility of transformation and resisting the reification of contingent institutions, Morgenthau was actually a true realist as there is nothing more real than change. ${ }^{87}$

In these instances, international theory becomes the site in which IR scholars exercise not merely their dissident role but also employ their political imagination in the fray of everyday politics and collective engagement. In the absence of an undisputed ontological, epistemic or axiological foundation for their scholarly interventions, public relevance and scrutiny remains the ultimate litmus test of their critical interventions. Morgenthau himself was acutely aware of that critical aspect of international theory as the conscience of policy-makers and mankind in general. ${ }^{88}$ His commitment to a publicly relevant IR, often incurring a personal cost, 89 is underpinned by a view of politics as a grounding exercise in the absence of an ultimate ground, a site where individual and collective value commitments clash or converge with no privileged access to truth. Much in line with the post-structuralist emphasis on the critical role of the intellectual, for Morgenthau, the political was the personal indeed. If, despite his vigilance, his strict separation of the realms of immanence and transcendence could crystallise into an implacable structure, that is symptomatic not only of the promising possibilities but also of the fragile nature and paradoxes surrounding the critical enterprise in IR. ${ }^{90}$

\footnotetext{
${ }^{86}$ For instances of such an enterprise, see William Bain, 'Deconfusing Morgenthau: moral inquiry and classical realism reconsidered', Review of International Studies, 26, (2000): 445-464; William E. Scheuerman, The Realist Case for Global Reform, (Cambridge: Polity Press, 2011); Robert Schuett, 'Peace through Transformation? Political Realism and the Progressivism of National Security', International Relations, 25, no. 2, (2011): 185-203; Tjalve, Realist Strategies; Lebow, The Tragic Vision of Politics; Campbell Craig, Glimmer of a New Leviathan: total war in the realism of Niebuhr, Morgenthau and Waltz, (New York: Columbia University Press, 2003).

87 Duncan Bell, 'Introduction: Under an Empty Sky-Realism and Political Theory' in Bell ed., Political Thought and International Relations, 10.

${ }^{88}$ Hans J. Morgenthau, 'The Intellectual and Political Functions of Theory' in Der Derian ed., International Theory: Critical Investigations, 49.

89 For a summary account of the negative consequences Morgenthau's dissident stance on Vietnam had on his career and reputation, see Rösch, 'The Human Condition of Politics', 12-13.

90 See Vassilios Paipais, 'Self and Other in Critical International Theory: Assimilation, Incommensurability and the Paradox of Critique', Review of International Studies, 37, no. 1, (2011): 121-140 and Kimberly Hutchings, Kant, Critique and Politics, (New York: Routledge, 1996). For criticisms that Morgenthau lacks a sustainable concept and practice of reflexivity that
} 


\section{Conclusion}

This paper engaged with the sophisticated realism of Hans J. Morgenthau and examined his theory of the political in conjunction with a postfoundationalist theorisation of the difference between politics and the political. In doing so, it managed to show how Morgenthau's double critique of depoliticisation refuses to circumscribe the element of antagonism pervading both the constitution and the conduct of politics. What became apparent from the critical revisiting of Morgenthau's position is not some hidden objective truth or 'verifiable' reality that escaped him and which this paper claims access to from a neutral, disengaged position. Rather, in an authentic act of criticism, as Rex Butler remarks, we do not seek to oppose the other(s) but, instead, bring out a certain 'internal contradiction' to them, in a sense repeat all that they are saying but for an entirely different reason. ${ }^{91}$ If this is true, then any act of criticism is not in what is being said but in the saying, not so much in the content but in its form. The task of the critic in this case is not to dwell on errors or limitations but to highlight what is more in a thinker than he himself was able or willing to recognise. The purpose of this critique, then, is not to identify lacunae in Morgenthau's arguments but to interrogate the 'transcendental' conditions of his discourse: that which is in it more than itself. ${ }^{92}$ It is this logic of heterogeneity that political difference stands for. ${ }^{93}$

Even Morgenthau's failure to fully overcome the temptation of depoliticisation can prove useful for critical thought. His irresolvable oscillation between Nietzschean skepticism and quasi-Kantian moral transcendence is not necessarily conservative as long as one reads it not as another structural necessity but, rather, as the condition of possibility of historicity itself. ${ }^{94}$ The hidden progressive possibilities of Morgenthau's double critique of depoliticisation are then revealed by a shifting of perspective because it is exactly 'in thinking that there is no alternative to what is that some alternative is

eventually compromises his ability to imagine new repoliticising possibilities, see Daniel Levine, Recovering International Relations: The Promise of Sustainable Critique, (Oxford: Oxford University Press), 131-35 and Inanna Hamati-Ataya, 'Knowing and Judging in International Relations Theory: realism and the reflexive challenge', Review of International Studies, 36, no. 4, (2010): 1087.

91 Butler, Slavoj Žižek: live theory, 126.

92 Compare with Lebow, The Tragic Vision of Politics, 56: 'Generations of engagement with a text identify anomalies, draw out hidden meanings and find new questions that result in fuller, more varied and complex readings. Over time, these interpretations...establish a tradition that provides readers with insights and understandings that were unavailable to their predecessors or even to the author.'

${ }^{93}$ For a similar argument that sees political realism as recognising the heterogeneity arising out of the dialectical nature of reality, see Griffiths, Realism, Idealism and International Politics; that said, this paper does not necessarily agree with Griffiths' assessment of Morgenthau. For genealogical readings emphasising the heterogeneity of 'realism' or, better, realisms, see Der Derian, 'A Reinterpretation of Realism' and Sean Molloy, 'From The Twenty Years' Crisis to Theory of International Politics: a rhizomatic reading of realism', Journal of International Relations and Development, 13, (2010): 378-404.

94 Slavoj Žižek, 'Class Struggle or Postmodernism?' in Judith Butler, Ernesto Laclau and Slavoj Žižek, Contingency, Hegemony, Universality: contemporary dialogues on the Left, (London and New York: Verso, 2000), 108. 
opened up'. ${ }^{95}$ All significant critical theory is this drive: incessantly encircling the impossibility of something existing 'outside what is' and in the very thinking of this the production of a certain 'excess' or 'gap'. ${ }^{96}$ All critical theory then is a 'forced choice', an exercise of freedom in necessity that produces its own excess and through this act of repetition new avenues of repoliticisation are broached. If International Relations theory is to join in this endeavour, then it must repeat everything that comes before it unchanged and its own image must be remade as post-foundational political ontology. Instead of inviting passivity or despair, the paradox of political difference may then become the condition of possibility for a constant re-politicisation of our political imaginary in critically constructing new modes of political and social organisation in global politics.

95 Butler, Slavoj Žižek: live theory, 138.

96 Slavoj Žižek, S., On Belief, (New York: Routledge, 2001), 92-5. 